\title{
Pelatihan Basic Human Factor untuk Peningkatan Self Awareness dan Safety Culture Petugas Operasi Bandar Udara Gusti Syamsir Alam
}

\author{
Direstu Amalia \\ Politeknik Penerbangan Palembang \\ e-mail: direstu@poltekbangplg.ac.id \\ Wildan Nugraha \\ Politeknik Penerbangan Palembang \\ e-mail:wildan.nugraha@poltekbangplg.ac.id \\ Viktor Suryan \\ Politeknik Penerbangan Palembang \\ e-mail:viktor@poltekbangplg.ac.id \\ Virma Septiani \\ Politeknik Penerbangan Palembang \\ e-mail:vvirmaseptiani@poltekbangplg.ac.id \\ Belen Sri H Napitulu \\ Politeknik Penerbangan Palembang \\ e-mail:balen@poltekbangplg.ac.id
}

\begin{abstract}
Abstrak
Studi tentang human factor adalah tentang memahami perilaku (behaviour) dan kinerja (performance) manusia (human). Ketika diterapkan pada operasi penerbangan, human factor digunakan untuk mengoptimalkan hubungan antara manusia (human) dan sistem (system) tempat mereka bekerja (workplace) untuk meningkatkan keselamatan (safety) dan kinerja (performance). Gambaran tentang efek human factor dalam penerbangan serta pentingnya self-awareness akan dijabarkan pada diklat ini. Hasil pelatihan yang memuaskan dicapai oleh 16 orang, 8 orang baik sekali, dan 2 orang berpredikat baik dengan range nilai tertinggi 94,70 dan nilai terendah 74,25 .
\end{abstract}

Kata kunci: human factor training, safety management system

\begin{abstract}
The study of human factors is about understanding human behavior and performance. When applied to flight operations, human factors are used to optimize the relationship between humans and the system they work in to improve safety and performance. An overview of the effects of human factors in aviation and the importance of self-awareness will be explained in this training. Satisfactory training results were achieved by 16 people, 8 very good people, and 2 people with good credentials with the highest score range of 94.70 and the lowest score of 74.25 .
\end{abstract}

Keywords: human factor training, safety management system

\section{Pendahuluan}

Manusia merupakan komponen utama dari sebuah sistem, manusia juga menjadi pemegang keputusan atau decision making terhadap suatu kejadian sehingga perlu diberi perhatian dan pelatihan serius terkait peran mereka yang cukup vital dalam berjalannya proses safety management system di suatu organisasi (Amalia, 2019). Human Factor atau disebut sebagai Faktor Manusia 
Direstu Amalia, Wildan Nugraha, Viktor Suryan, Virma Septiani, Belen Sri H Napitulu

Pelatihan Basic Human Factor untuk Peningkatan Self Awareness dan Safety Culture Petugas Operasi Bandar Udara Gusti Syamsir Alam

adalah suatu bidang ilmu yang mempelajari tentang hubungan atau interaksi manusia dengan elemen lain dalam sebuah sistem, human factor juga disebut sebagai bidang ilmu yang berupa konsep teoritis yang mempelajari cara agar kinerja manusia dapat optimal sehingga performa sistem secara keseluruhan pun meningkat.

\section{Shell Model}

Dalam konsep human factor yang dijelaskan dalam dokumen 9859 safety management system manual (ICAO, 2018) disebutkan istilah human in the system yang pertama kali dikembangkan oleh Edwards pada tahun 1972 dan diilustrasikan dalam gambar oleh Hopkins di tahun 1975. Konsep manusia dan hubungannya dengan sistem ini dikenal sebagai SHELL Model yang kemudian menjadi alat referensi mengembangkan konsep human factor. Diagram ini hanya mencakup hubungan manusia dengan komponen lainnya, dan bukan diperuntukkan untuk hubungan antar muka (software-software, hardware-software atau hardware-environment).

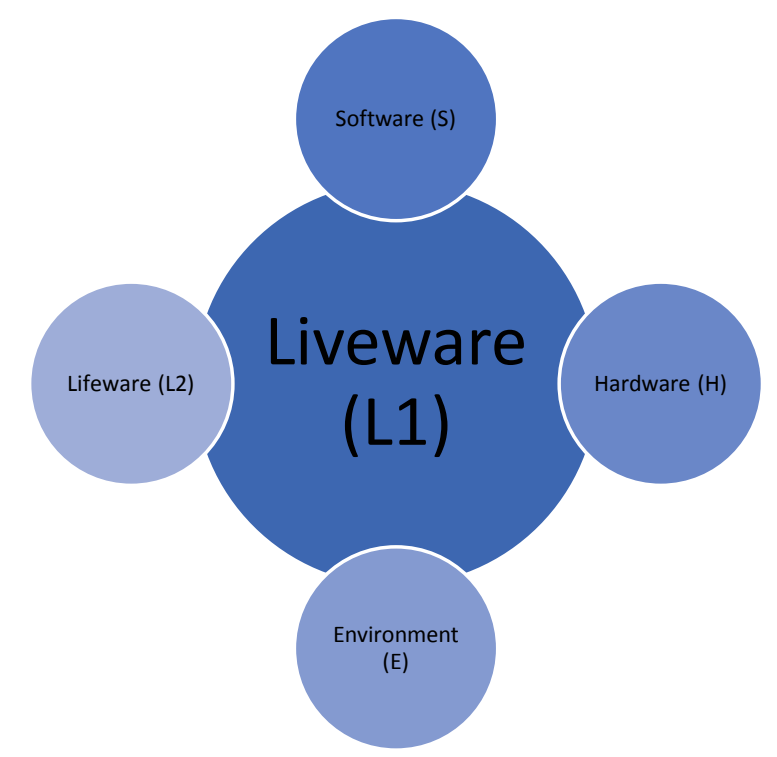

Gambar 1. SHELL Model hubungan Manusia dalam Sistem/Organisasi

Hubungan secara teoritis antara Manusia (L) dengan aturan/prosedur (S), peralatan kerja (H), kondisi lingkungan kerja (E), serta hubungan dengan manusia/pekerja lain (L2) ditunjukkan pada gambar diatas. Pada gambar ditunjukkan bahwa (L) menjadi inti dari sebuah sistem. Menurut Model SHELL, ketidakcocokan antara Liveware (L1) dan empat komponen lainnya berkontribusi pada human factor sehingga interaksi ini harus dikontrol, dinilai dan dipertimbangkan di semua sistem operasi penerbangan.

Dalam konsep accident cause cheese model, manusia dikenal sebagai active failure atau komponen yang mengaktifkan kecelakaan/kejadian itu sendiri. Peran manusia adalah bagian paling kritis dalam SHELL Model. Manusia menjadi komponen yang paling penting sekaligus 
Direstu Amalia, Wildan Nugraha, Viktor Suryan, Virma Septiani, Belen Sri H Napitulu

Pelatihan Basic Human Factor untuk Peningkatan Self Awareness dan Safety Culture Petugas Operasi

Bandar Udara Gusti Syamsir Alam

paling fleksibel di dalam sebuah sistem. Manusia sebagai makhluk yang imperfect, harus didukung oleh komponen lain dari sistem, dan perlu dicocokkan dengan hati-hati jika ingin tekanan dalam sistem dan kerusakan-kerusakan yang mungkin timbul ingin dihindari.

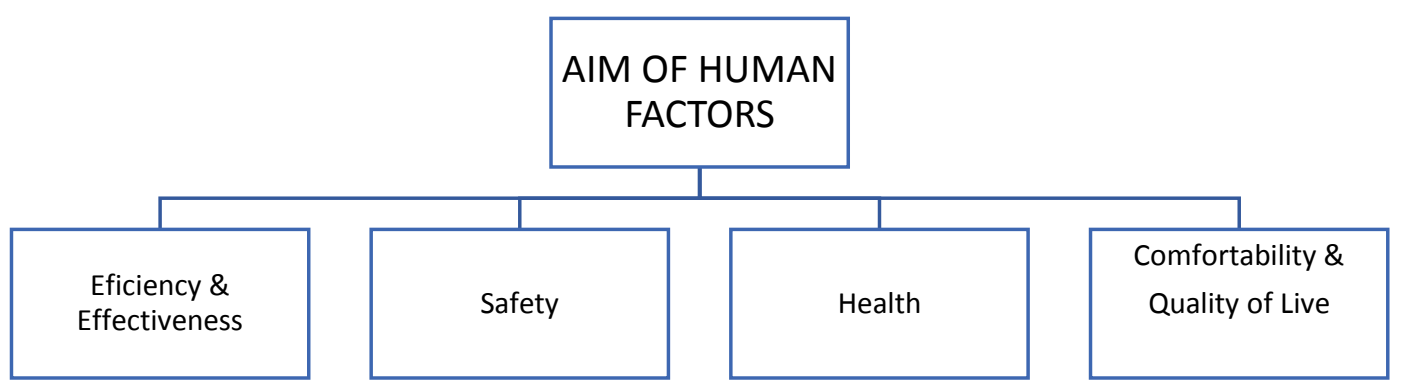

Gambar 2. Tujuan Pelaksanaan Diklat Human Factors

Hal-hal seperti: 1) perekrutan SDM yang sesuai dengan kebutuhan, 2) peningkatan kualitas sdm dengan pelatihan, penciptaan suasana yang kondusif dalam lingkungan kerja termasuk alat kerja yang memadai, 3) serta prosedur/aturan yang memihak pekerja. Dengan adanya usaha-usaha tersebut, diharapkan manusia tersebut mampu membuat keputusan, resiko-resiko accident atau kerugian lain dapat dihindari sehingga performa kerja dapat disebut sebagai efektif dan efisien. Hal lain yang juga penting, bahwa kualitas sdm dan kompetensi yang terpenuhi mampu meningkatkan self-awareness yang memiliki peran penting khususnya dalam mengidentifikasi potensi bahaya yang dapat berdampak pada operasi penerbangan; kemudian melakukan perbaikan yang diperlukan untuk menjaga kinerja keselamatan; observasi berkelanjutan dan penilaian rutin kinerja keselamatan; serta penyempurnaan berkelanjutan dari keseluruhan kinerja sistem manajemen keselamatan (Nugraha, 2019). Sehingga bisa dikatakan bahwa, sebuah diklat dilaksanakan untuk membuat manusia (human) dapat membuat sistem berkerja denga performa yang diharapkan.

\section{The Human Factor "Dirty Dozen"}

Berdasarkan hasil survey pada jumlah insiden dan kecelakaan pada ATC, ditemukan bahwa human factor masih menduduki peringkat pertama sebagai factor utama (Tao, Wenbing, \& Ke, 2019). Hal ini menjadi pengingat sekaligus ancaman berat yang harus dicarikan solusinya. 
Direstu Amalia, Wildan Nugraha, Viktor Suryan, Virma Septiani, Belen Sri H Napitulu

Pelatihan Basic Human Factor untuk Peningkatan Self Awareness dan Safety Culture Petugas Operasi Bandar Udara Gusti Syamsir Alam

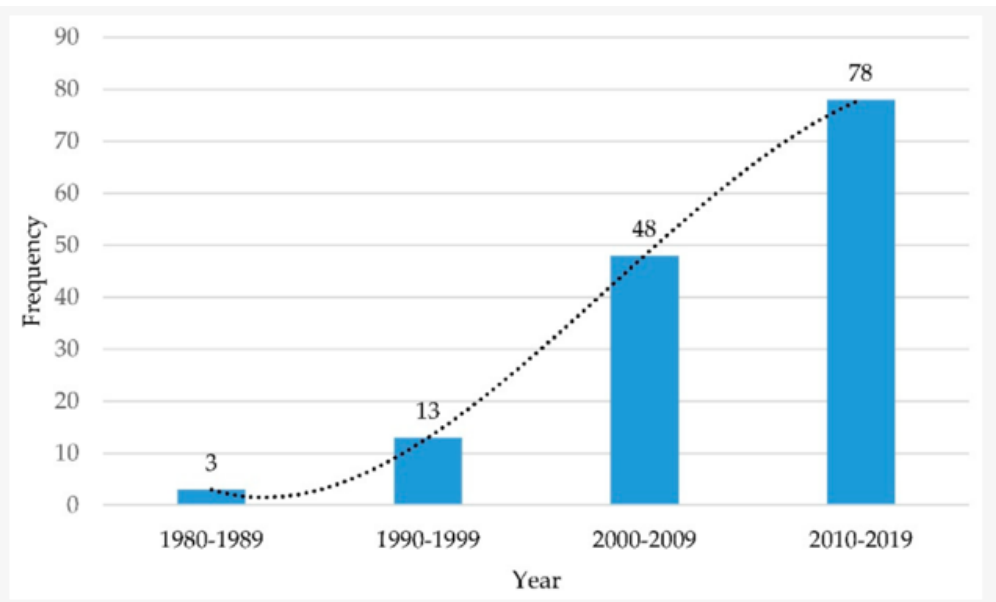

Gambar 3. Jumlah Insiden/Kecelakaan yang Berhubungan dengan Human Factor pada ATC

Tahun 1980-2019. (Tao, Wenbing, \& Ke, 2019)

Gordon Dupont pada tahun 1993 melakukan sebuah penelitian terkait 12 penyebab human error yang paling sering terjadi dan dikenal dengan sebutan dirty dozen (skybrary.aero, 2020). Dirty Dozen dapat dikatakan sebagai dua belas prasyarat human error yang paling umum, atau kondisi yang dapat bertindak sebagai prekursor, untuk kecelakaan (accident) maupun insiden (incident) khususnya di dunia penerbangan.

Dirty Dozen telah meningkatkan kesadaran tentang bagaimana manusia dapat berkontribusi terhadap kecelakaan dan insiden, tujuan dari konsep ini adalah untuk memfokuskan perhatian dan sumber daya untuk mengurangi dan memonitor human error. Sehingga elemen pada daftar The Dirty Dozen juga memuat contoh tindakan pencegahan yang dirancang guna mengurangi kemungkinan human error yang menyebabkan masalah.

\section{Dirty Dozen}

- Lack of Communication

- Distraction

- Lack of Resources

-Stress

- Complacency

- Lack of teamwork

-Pressure

- Lack of Awareness

- Lack of knowledge

- FATIGUE

- Lack of Assertiveness

-NORMS

Gambar 4. Human Factor Dirty Dozen 
Direstu Amalia, Wildan Nugraha, Viktor Suryan, Virma Septiani, Belen Sri H Napitulu

Pelatihan Basic Human Factor untuk Peningkatan Self Awareness dan Safety Culture Petugas Operasi Bandar Udara Gusti Syamsir Alam

\section{Metode}

Kegiatan pengabdian masyarakat dalam bentuk Diklat Human Factor ditujukan kepada pegawai operasional bandar udara, dilaksanakan secara tatap muka langsung di Bandara Gusti Syamsir Alam Kotabaru Provinsi Kalimantan Tengah. Kegiatan dilaksanakan selama 3 (tiga) hari berupa materi basic human factor dengan metode ceramah, diskusi kelompok, tanya jawab dan ujian tertulis.

International commission on education mengeluarkan pernyataan terhadap 4 (empat) pilar pendidikan demi tercapainya long live education atau Pendidikan sepanjang hayat. 4 pilar tersebut yaitu: (1) learning to know; (2) learning to do; (3) learning to be, dan (4) learning to live together. Hal ini menjadi dasar penerapan student-centered learning yang arahnya menuju collaborative learning yaitu pendekatan pendidikan untuk pengajaran dan pembelajaran yang melibatkan kelompok siswa yang bekerja bersama untuk memecahkan masalah, menyelesaikan tugas, atau membuat produk.

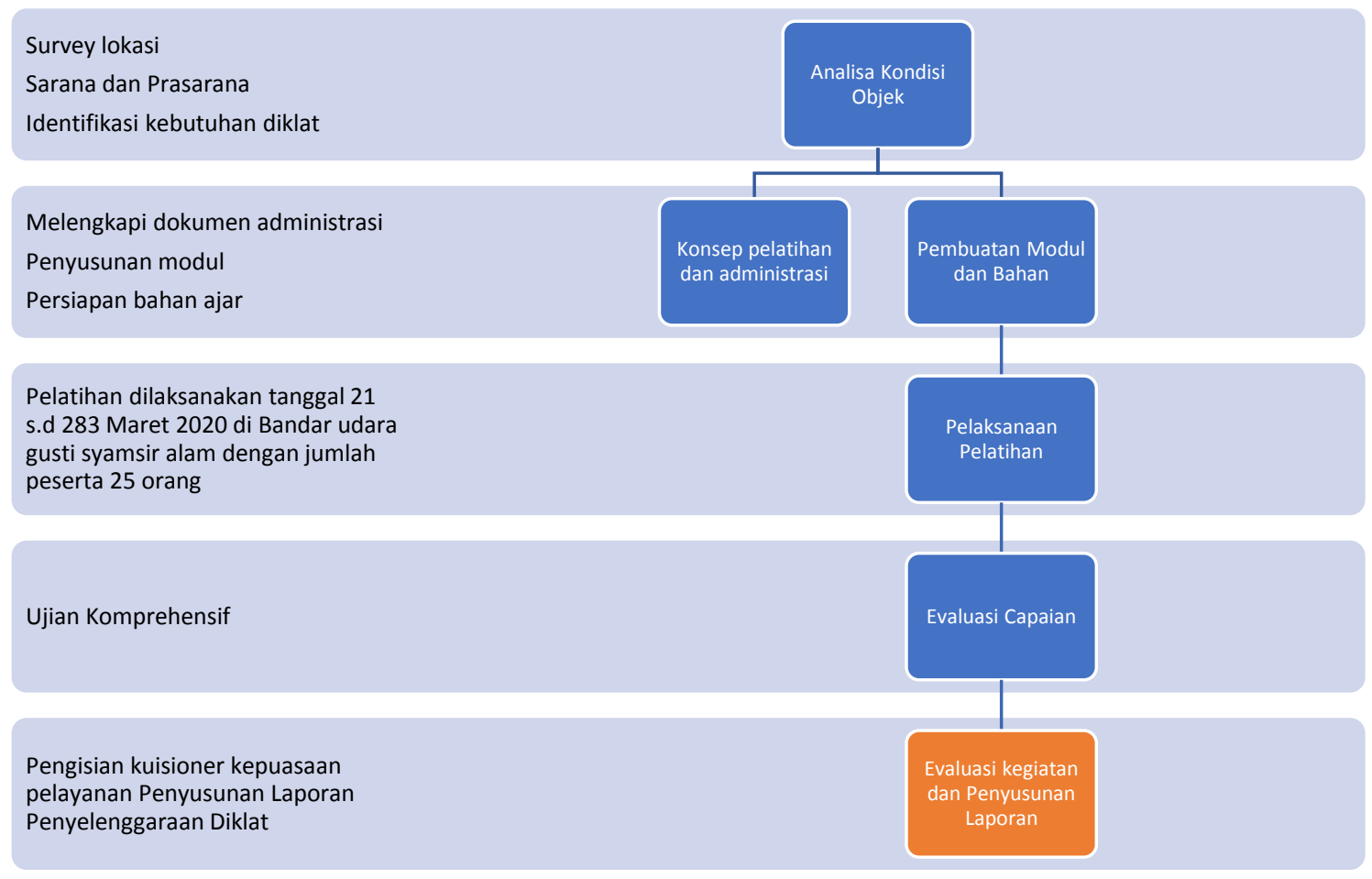

Gambar 5. Tahapan Kegiatan PKM

\section{Hasil dan Pembahasan}

\section{Konsep Diklat Human Factor}

Peserta diklat ini memiliki latar belakang teknis dan non teknis, mereka berasal dari berbagai disiplin ilmu serta latar belakang pekerjaan yang berbeda pula. Pengetahuan terkait human factor yang dimiliki belum ada, dan diklat ini diperuntukkan sebagai diklat pembekalan bagi para peserta. 
Direstu Amalia, Wildan Nugraha, Viktor Suryan, Virma Septiani, Belen Sri H Napitulu

Pelatihan Basic Human Factor untuk Peningkatan Self Awareness dan Safety Culture Petugas Operasi Bandar Udara Gusti Syamsir Alam

Untuk itu, kurikulum yang ditetapkan telah merujuk pula kepada training modul yang dikeluarkan oleh ICAO dan disesuaikan isinya dengan kebutuhan dasar para peserta diklat. Tujuan setelah menyelesaikan modul ini, peserta akan mampu: 1) Memahami komponen dasar human factor dan hubungannya dengan safety management system, 2) Bagaimana faktor manusia berhubungan erat dengan pengoperasian dan keselamatan bandara udara, 3) Bagaimana upaya peningkatan level keselamatan melalui penerapan strategi dasar.

\section{Materi dan Suasana Belajar}

Diklat ini merupakan pelatihan dasar human factor utk petugas operasi bandar udara, dengan latar belakang pendidikan dan bidang yang berbeda. Diklat ini diharapkan menjadi basic knowledge terkait peran setiap petugas dalam menciptakan keselamatan penerbangan.

Tabel 1. Penjabaran Materi Diklat

\begin{tabular}{|c|c|}
\hline Bagian & Penjabaran Materi \\
\hline $\begin{array}{l}\text { Hari ke-1 } \\
\text { Definisi, Regulasi, Konsep Faktor Manusia }\end{array}$ & $\begin{array}{l}\text { - } \text { Memahami pentingnya mempelajari } \\
\text { Faktor Manusia } \\
\text { - } \text { Menentukan Faktor-faktor Manusia } \\
\text { - } \text { Memahami pentingnya Faktor } \\
\text { Manusia dalam kaitannya dengan } \\
\text { keselamatan } \\
\text { - } \text { Mengetahui dan menjelaskan } \\
\text { komponen model SHELL. } \\
\text { - } \text { Diskusi kelompok } \\
\text { - } \text { Presentasi hasil diskusi kelompok }\end{array}$ \\
\hline $\begin{array}{l}\text { Hari ke-2 } \\
\text { Human Factor dan Safety Operation di } \\
\text { Bandar Udara }\end{array}$ & $\begin{array}{l}\text { - Memahami hubungan antara Faktor } \\
\text { Manusia dan Sistem Manajemen } \\
\text { Keselamatan } \\
\text { - Menjelaskan Faktor Manusia utama } \\
\text { yang mempengaruhi efektivitas } \\
\text { Sistem Manajemen Keselamatan } \\
\text { - Menjelaskan faktor manusia utama } \\
\text { yang mempengaruhi kinerja manusia } \\
\text { - Diskusi kelompok } \\
\text { - Presentasi hasil diskusi kelompok }\end{array}$ \\
\hline $\begin{array}{l}\text { Hari ke-3 } \\
\text { Menangani Human Factor }\end{array}$ & $\begin{array}{l}\text { - Memahami bagaimana kesalahan } \\
\text { terjadi karena kondisi laten dan } \\
\text { kegagalan aktif } \\
\text { - Menjelaskan sumber utama kesalahan } \\
\text { faktor manusia } \\
\text { - Memahami strategi utama untuk } \\
\text { menangani kesalahan faktor manusia }\end{array}$ \\
\hline $\begin{array}{l}\text { Hari ke-3 } \\
\text { Ujian Komprehensif }\end{array}$ & - 5 Soal pilihan ganda dan 1 essay \\
\hline
\end{tabular}


Direstu Amalia, Wildan Nugraha, Viktor Suryan, Virma Septiani, Belen Sri H Napitulu

Pelatihan Basic Human Factor untuk Peningkatan Self Awareness dan Safety Culture Petugas Operasi Bandar Udara Gusti Syamsir Alam

a. Contoh tampilan konten materi presentasi.

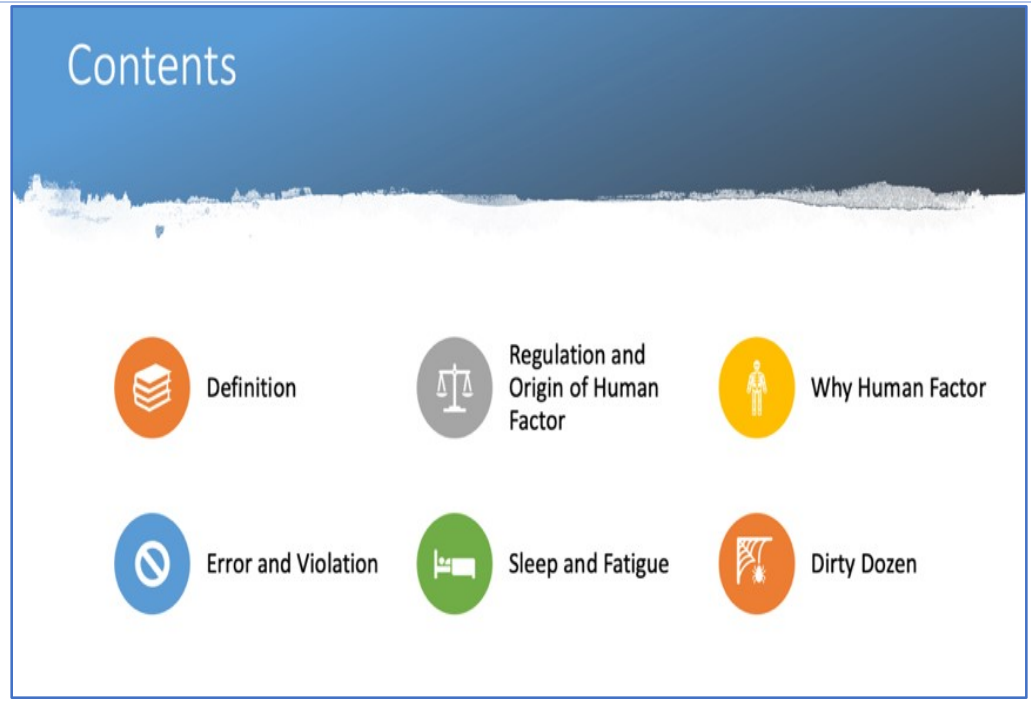

b. Salah satu konten materi yang diberikan.

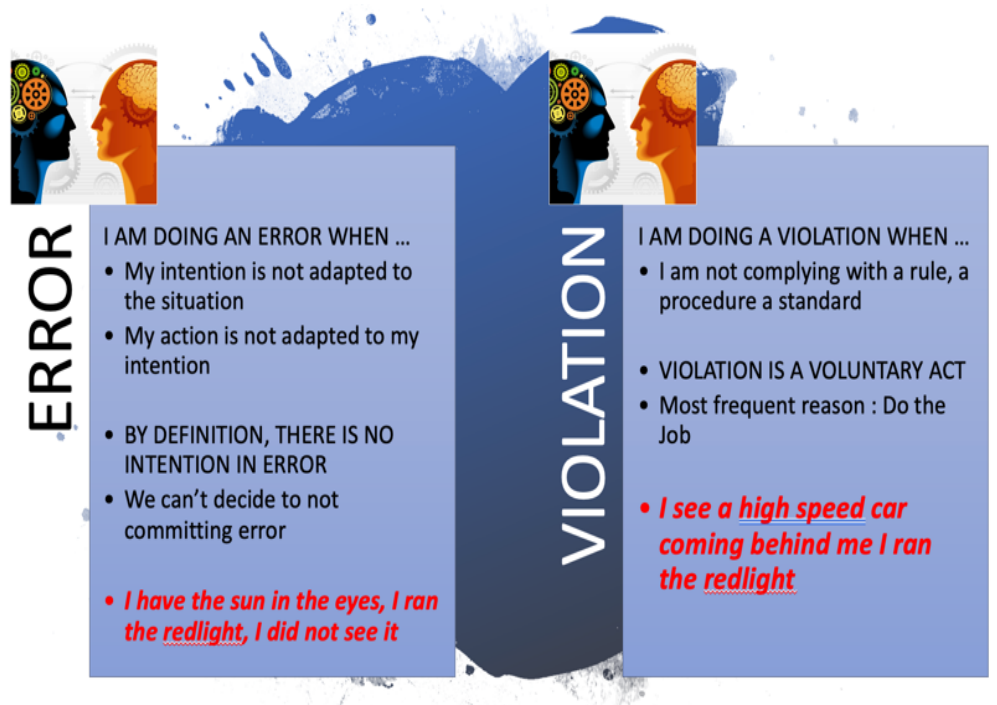

\section{Penilaian Peningkatan Kemampuan Peserta Diklat}

Diklat ini memiliki beberapa bentuk penilaian yaitu disiplin, keaktifan dikelas dan hasil belajar. Penilaian hasil belajar peserta dilakukan berdasarkan hasil diskusi kelompok, quiz, dan ujian komprehensif. 
Direstu Amalia, Wildan Nugraha, Viktor Suryan, Virma Septiani, Belen Sri H Napitulu

Pelatihan Basic Human Factor untuk Peningkatan Self Awareness dan Safety Culture Petugas Operasi Bandar Udara Gusti Syamsir Alam

HUMAN FACTOR TEST

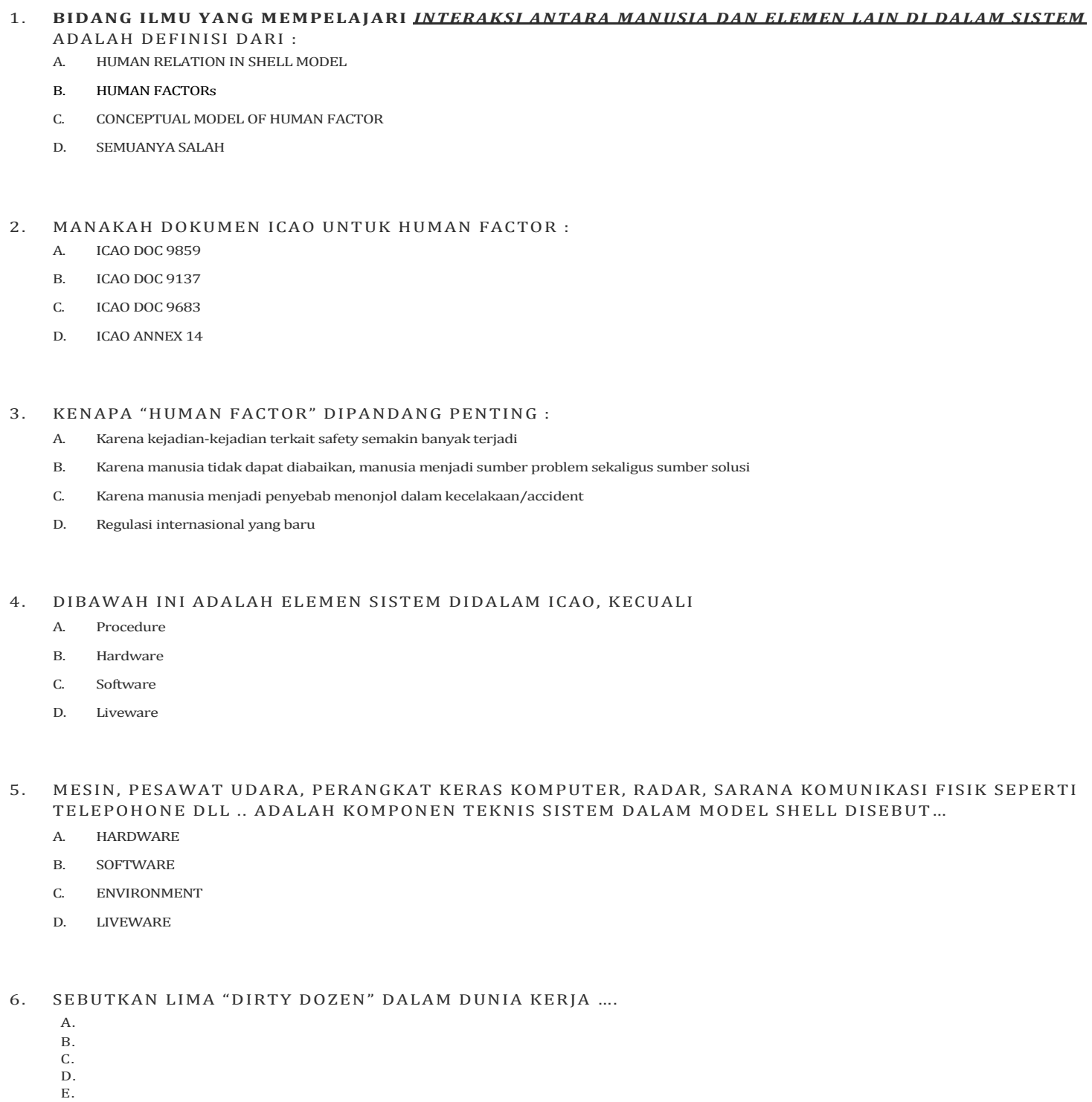

Gambar 6. Soal Ujian Komprehensif

\section{Hasil Belajar Peserta Diklat}

Ujian merupakan sesuatu cara formal untuk memberikan penilaian akhir dari informasi materi apa yang didapatkan oleh peserta diklat setelah diklat diselesaikan. Ujian juga menjadi alat untuk pengukuran kualitas dan kesesuaian materi pelatihan, sekaligus sebagai feedback dari kegiatan pelatihan secara keseluruhan. Sehingga ujian akhir masih dipandang perlu untuk dilaksanakan karena masih menjadi alat ukur kesuksesan pelatihan ini. 
Direstu Amalia, Wildan Nugraha, Viktor Suryan, Virma Septiani, Belen Sri H Napitulu

Pelatihan Basic Human Factor untuk Peningkatan Self Awareness dan Safety Culture Petugas Operasi Bandar Udara Gusti Syamsir Alam

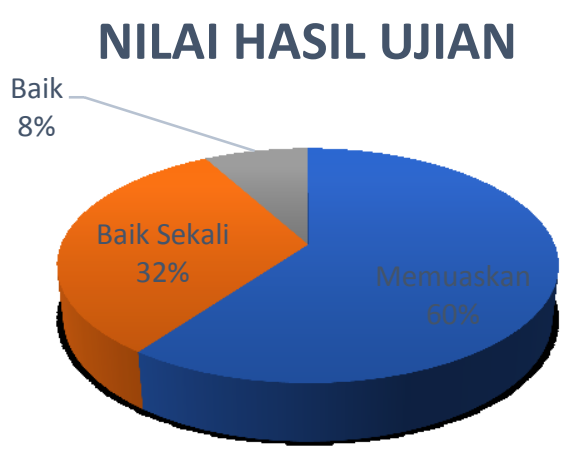

Gambar 7. Persentase Hasil Ujian Peserta

Dari data gambar diatas diketahui bahwa 60\% peserta atau 15 (lima belas) orang mendapatkan nilai dengan kategori "memuaskan", 32\% atau 8 (delapan) orang peserta mendapatkan nilai "baik sekali”, dan sisanya 2 orang mendapatkan nilai baik dengan persentase $8 \%$.

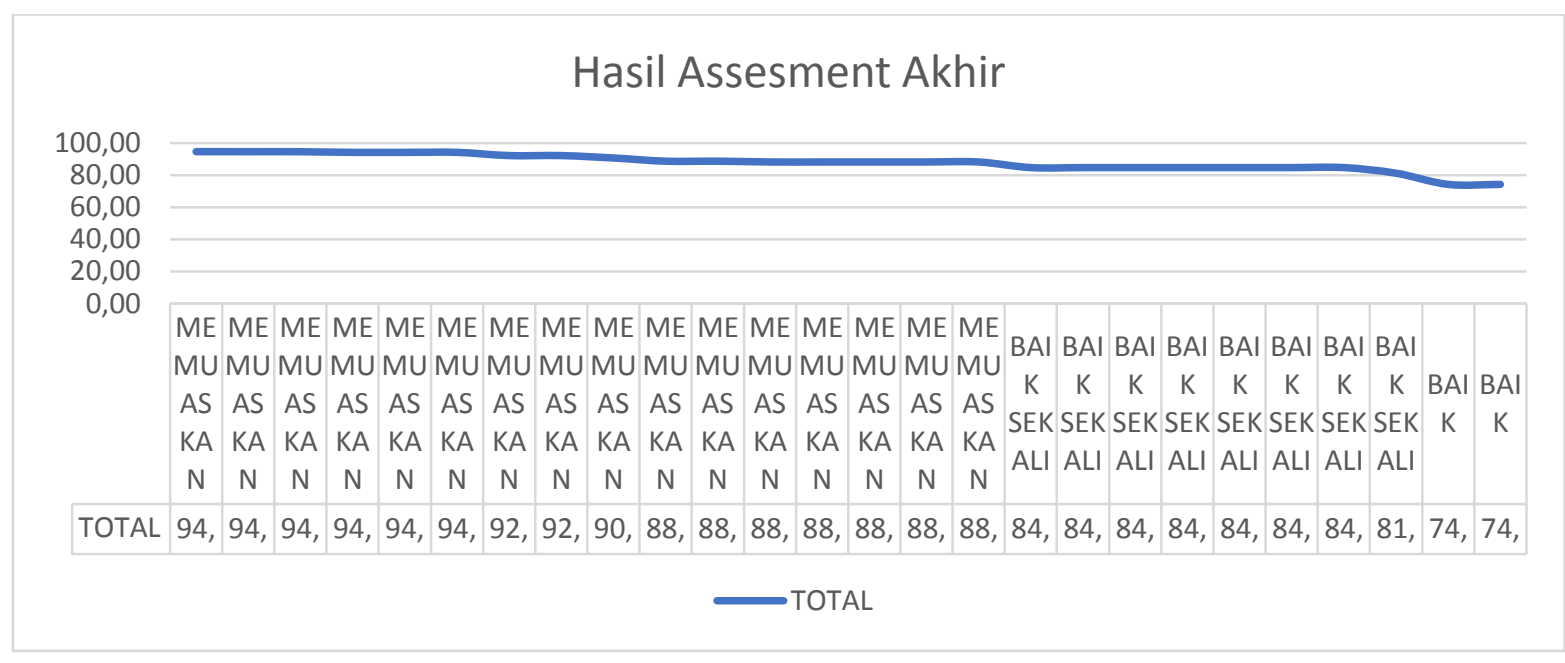

Gambar 8. Nilai Angka Hasil Ujian

\section{Kesimpulan}

Dari kegiatan ini penulis mendapatkan simpulan bahwa:

1. Manajemen Bandar Udara Gusti Syamsir Alam berkomitmen tinggi terhadap terselenggaranya safety management system

2. Manajemen Bandar Udara Gusti Syamsir Alam dan segenap jajaran petugas operasional bandar udara sangat kooperatif, bersedia membuka diri dan berkembang

3. Para peserta pelatihan memiliki minat belajar dan motivasi yang tinggi, serta kesadaran yang besar bahwa diri mereka menjadi sebuah "human factor" serta memiliki peran dalam penyelenggaraan safety culture dan safety management system. 
Direstu Amalia, Wildan Nugraha, Viktor Suryan, Virma Septiani, Belen Sri H Napitulu

Pelatihan Basic Human Factor untuk Peningkatan Self Awareness dan Safety Culture Petugas Operasi

Bandar Udara Gusti Syamsir Alam

\section{Ucapan Terima Kasih}

Terima kasih kami kepada civitas akademika Politeknik Penerbangan Palembang dan Manajemen Bandar Udara Gusti Syamsir Alam dan seluruh peserta pelatihan atas segala kerjasama yang baik sehingga kegiatan Diklat Basic Human Factor ini dapat terselenggara dengan baik sesuai yang direncanakan.

\section{Daftar Pustaka}

Amalia, D. (2019). Promoting Just Culture for Enhancing Safety Culture in Aerodrome Airside Operation. International Journal of Scientific \& Technology Research, 8(10), 260-266.

Nugraha, W. (2019). Safety Documentation: A Communication Approach for Safety Management System in Aerodrome Operator. International Journal of Scientific \& Technology Research, $8(11), 1705-1711$.

Tao, L., Wenbing, S., \& Ke, D. (2019). Human Factors Analysis of Air Traffic Safety Based on HFACS-BN Model. Applied Sciences.

skybrary.aero. (2020, march 21). Retrieved from skybrary: https://www.skybrary.aero/index.php/The_Human_Factors_\%22Dirty_Dozen\%22

ICAO. (2018). Doc 9859 Safety Management Manual. ICAO. 